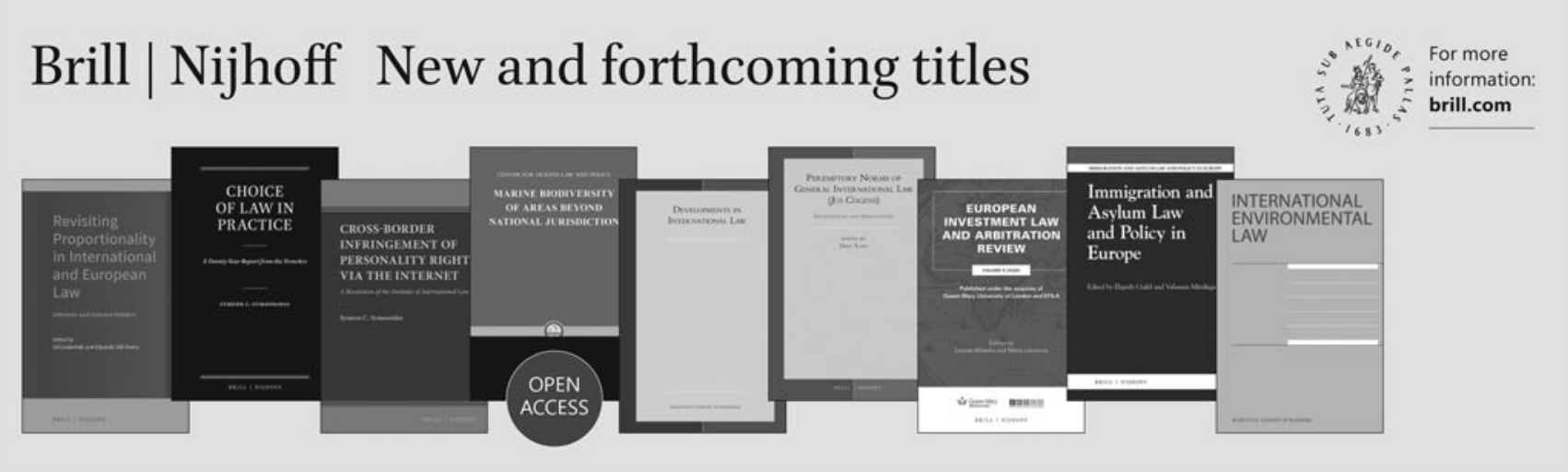

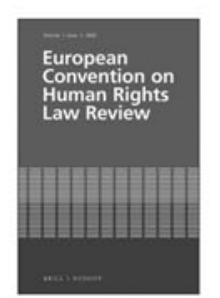

Free access for individuals see brill.com/eclr for more details.

\section{European Convention on Human Rights Law Review}

Editors-in-Chief: Kanstantsin Dzehtsiarou and Vassilis P. Tzevelekos

The first scholarly journal devoted exclusively to the legal regime of the European Convention on Human Rights (ECHR), offering peer-reviewed, legal scholarship on the protection of fundamental human rights within the ECHR framework and on its implications for other regional human rights regimes. It is a forum for inter alia comparative law, human rights law, international law and philosophy of law analysis of the practice and procedures of the ECHR regime.

\section{Revisiting Proportionality in International and European Law \\ Interests and Interest-Holders}

Edited by Ulf Linderfalk, Lund University, Sweden and Eduardo Gill-Pedro, Lund University, Sweden.

May 2021 | Hardback (approx. 240 pp.) | ISBN 9789004448063 | E-ISBN 9789004448070 | Price US\$ 185

\section{Choice of Law in Practice}

A Twenty-Year Report from the Trenches (Set of 3 )

Symeon C. Symeonides, Willamette University College of Law

December 2020 | Hardback (xxxvi, 1,895 pp.) | ISBN 9789004435872 | E-ISBN 9789004435889 | Price US\$ 806

\section{Cross-Border Infringement of Personality Rights via the Internet \\ A Resolution of the Institute of International Law}

Symeon C. Symeonides, Willamette University College of Law

January 2021 | Hardback (xii, 408 pp.) | ISBN 9789004437630 | E-ISBN 9789004437647 | Price US\$ 258

\section{Marine Biodiversity of Areas beyond National Jurisdiction}

Edited by Myron H. Nordquist, University of Virginia School of Law; and Ronán Long, World Maritime University - Sasakawa Global Institute

February 2021 | Hardback (xx, 352 pp.) | ISBN 9789004422414 | Price $€ 161$ / US\$ 194 | E-ISBN 9789004422438 | Open Access | Center for Oceans Law and Policy, 24

\section{Head of State Immunity under the Malabo Protocol}

Triumph of Impunity over Accountability?

Kobina Daniel

September 2021 | Hardback | ISBN 9789004466074 | E-ISBN 9789004466081 | Price US\$ 194 | Developments in International Law, 76
Peremptory Norms of General International Law (Jus Cogens) Disquisitions and Disputations Edited by Dire Tladi

August 2021 | Hardback | ISBN 9789004464117 | E-ISBN 9789004464124 | Price US\$285 | Developments in International Law, 75

\section{European Investment Law and} Arbitration Review

Volume 5 (2020), Published under the auspices of Queen Mary University of London and EFILA

Edited by Loukas Mistelis, Queen Mary University of London and Nikos Lavranos, LLM, Free University Brussels

December 2020 | Hardback (xii, 482 pp.) | ISBN 9789004445147 | Price US\$ 516 | European Investment Law and Arbitration Review, 5 | online: brill.com/eilo

\section{Aliens before the European Court of Human Rights Ensuring Minimum Standards of Human Rights Protection}

Edited by David Moya, University of Barcelona, and Georgios Milios, University of Barcelona

August 2021 | Hardback (approx. 340 pp.) | ISBN 9789004465688 | E-ISBN 9789004465695 | Price US\$ $159 \mid$ Immigration and Asylum Law and Policy in Europe, 49

\section{A Multifaceted Approach to Trade Liberalisation and Investment Protection in the Energy Sector}

Edited by Elena Cima and Makane Moïse Mbengue

August 2021 | Hardback | ISBN 9789004463479 | E-ISBN 9789004463486 | Price US\$132 | International Environmental Law, 15

\section{BRILL | NIJHOFF}




\section{Brill $\mid$ Nijhoff New and forthcoming titles}

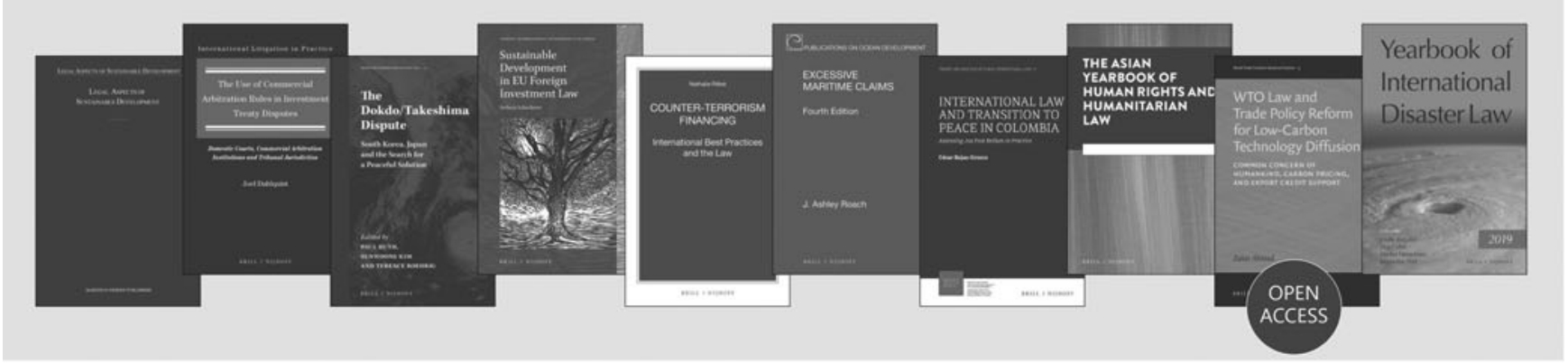

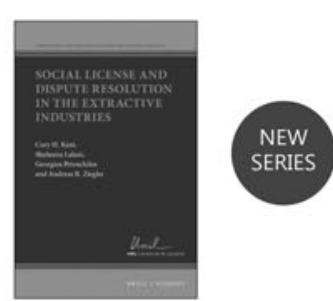

\section{Social License and Dispute Resolution in the Extractive Industries}

Cory H. Kent, Shaheeza Lalani, Georgios Petrochilos and Andreas R. Ziegler

This first volume in the new series International and Comparative Business Law and Public Policy, is a broad collection offering insights from both renowned academics and practitioners on the intersection of international dispute resolution and the social license to operate in the extractive industries. With its combined academic and practical perspective, the book focuses on mining disputes and addresses a broad array of issues, such as third party funding, grievance and redress, as well as the protection of human rights and the environment. In addition, it is the first work in the market that discusses the proposed rules of the world's first and only Global Natural Resources Dispute Resolution Center (GNDC).

March 2021 | Hardback (xii, 223 pp.) | ISBN 9789004450103 | E-ISBN 9789004450165 | Price US\$ 153 | International and Comparative Business Law and Public Policy, 1

\section{Sustainable Energy Democracy and the Law}

Edited by Ruven Fleming, Kaisa Huhta and Leonie Reins

September 2021 | Hardback | ISBN 9789004465435 | E-ISBN 9789004465442 | Price US\$ 172 | Legal Aspects of Sustainable Development, 26

\section{The Use of Commercial}

Arbitration Rules in Investment Treaty Disputes

Domestic Courts, Commercial Arbitration Institutions and Tribunal Jurisdiction Joel Dahlquist

March 2021 | Hardback (xii, 333 pp.) | ISBN 9789004413672 | E-ISBN 9789004413689 | Price US\$ 172 International Litigation in Practice, 11

\section{The Dokdo/Takeshima Dispute}

South Korea, Japan and the Search for a Peaceful Solution

Paul Huth, Sunwoong Kim and Terence Roehrig

April 2021 | Hardback (xiv, 254 pp.) | ISBN 9789004447882 | E-ISBN 9789004447899| Price US\$ 166 | Maritime Cooperation in East Asia, 10

\section{Sustainable Development in EU Foreign Investment Law} Stefanie Schacherer

September 2021 | Hardback | ISBN 9789004465879 | E-ISBN 9789004465886 | Price US\$198| Nijhoff International Investment Law Series, 19

\section{Artificial Intelligence: Robot Law, Policy and Ethics Nathalie Rébé}

June 2021 | Paperback (approx. 215 pp.) | ISBN 9789004458093 | E-ISBN 9789004458109 | Price US\$ 113 Nijhoff Law Specials, 102

\section{Excessive Maritime Claims Fourth Edition}

\section{J. Ashley Roach}

March 2021 | Hardback (lxxxiv, 867 pp.) | ISBN 9789004443518 | E-ISBN 9789004443532 | Price US\$ 345 | Publications on Ocean Development, 93

\section{International Law and}

Transition to Peace in Colombia Assessing Jus Post Bellum in Practice

\section{César Rojas-Orozco}

August 2021 | Hardback | ISBN 9789004440524 | E-ISBN 9789004440531 | Price US\$ 146| Theory and Practice of Public International Law, 3

\section{The Asian Yearbook of Human Rights and Humanitarian Law} Volume 5

Edited by Javaid Rehman, Brunel University, United Kingdom, Ayesha Shahid, Coventry University, United Kingdom and Steve Foster, Coventry University, United Kingdom.

Guest Editor: Frederick Cowell, School of Law, Birkbeck College University of London

September 2021 | Hardback (approx. 480 pp.) | ISBN 9789004466159 | E-ISBN 9789004466180 | Price US\$ 378 | The Asian Yearbook of Human Rights and Humanitarian Law, 5

\section{WTO Law and Trade Policy Reform for Low-Carbon Technology Diffusion} Common Concern of Humankind, Carbon Pricing, and Export Credit Support

\section{Zaker Ahmad}

February 2021 | Hardback (xvi, 307 pp.) | ISBN 9789004446083 | Price US\$ 179 | E-ISBN 9789004446090 | Open Access | World Trade Institute Advanced Studies, 5

\section{Yearbook of International \\ Disaster Law \\ Volume 2 (2019)}

Edited by Giulio Bartolini, Dug Cubie, Marlies Hesselman, and Jacqueline Peel

February 2021 | Hardback (x, 583 pp.) | ISBN $9789004445697 \mid$ Price US\$216 | Yearbook of International Disaster Law, 2 | online: brill.com/yido

\section{BRILL | NIJHOFF}




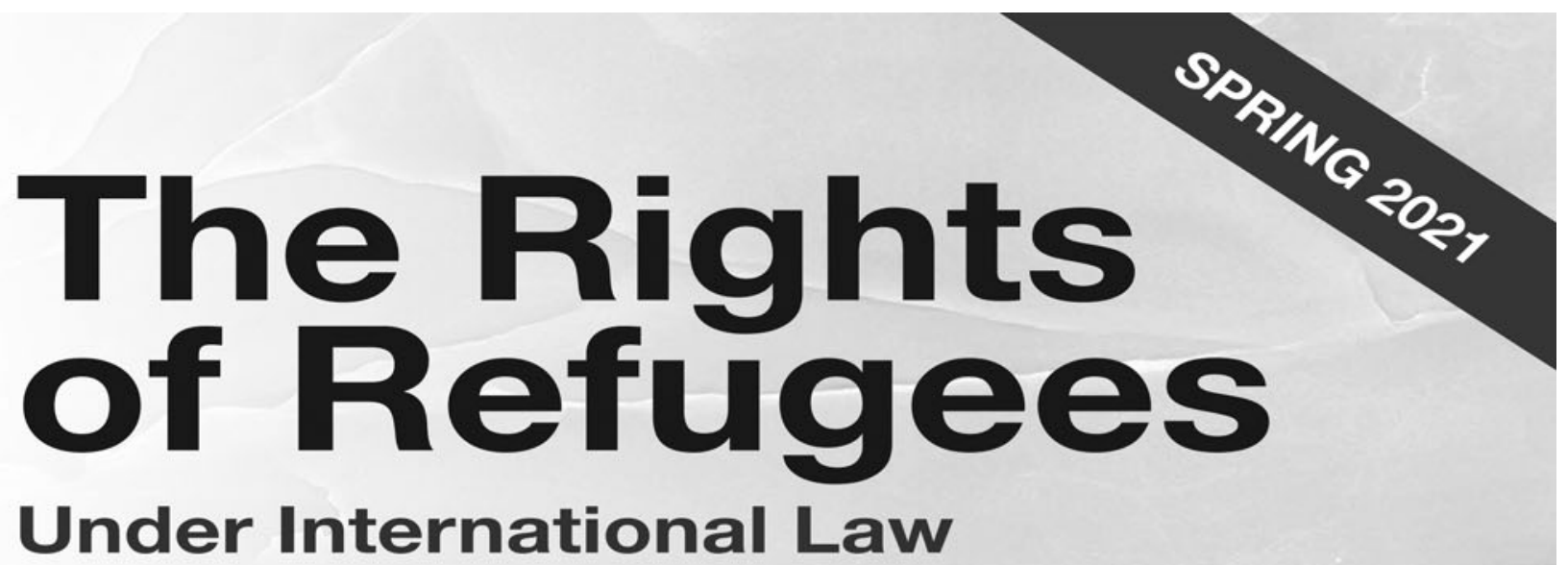

\section{SECOND EDITION}

James C. Hathaway, University of Michigan Law School

\section{PRAISE FOR THE FIRST EDITION:}

“... The authoritative comprehensive commentary of the [Refugee] Convention. As usual, the strength of Hathaway's approach lies in the precision of his legal analysis."

Catherine Phuong, Human Rights Law Review

“... The fundamental opus of international refugee law." Kay Hailbronner, International Journal of Refugee Law

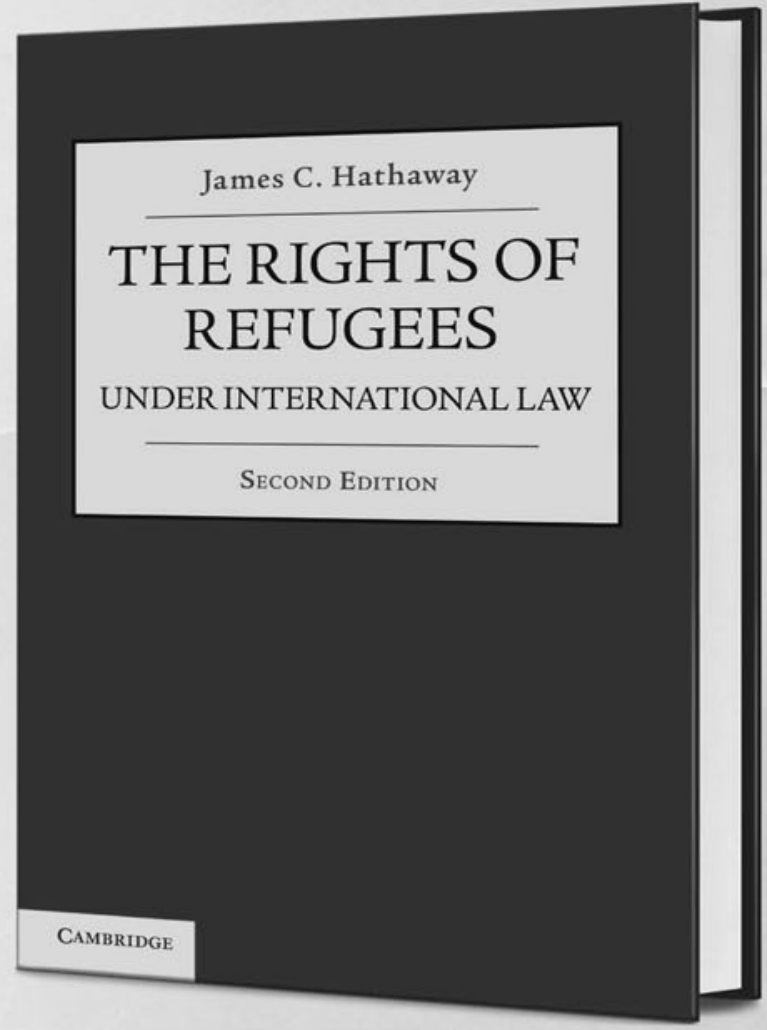

FIRST EDITION: WINNER OF THE CERTIFICATE OF MERIT, AMERICAN SOCIETY OF INTERNATIONAL LAW, 2007 

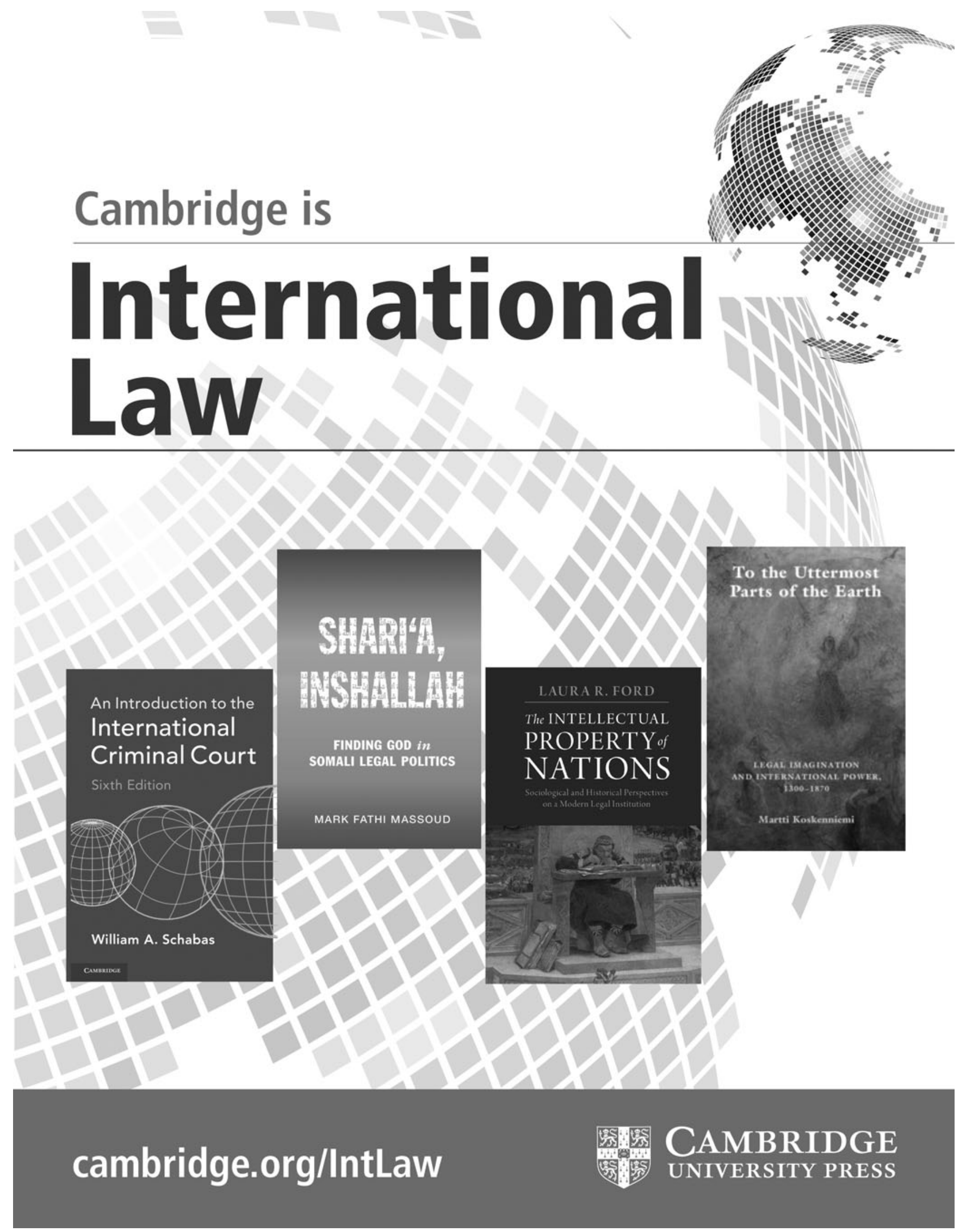


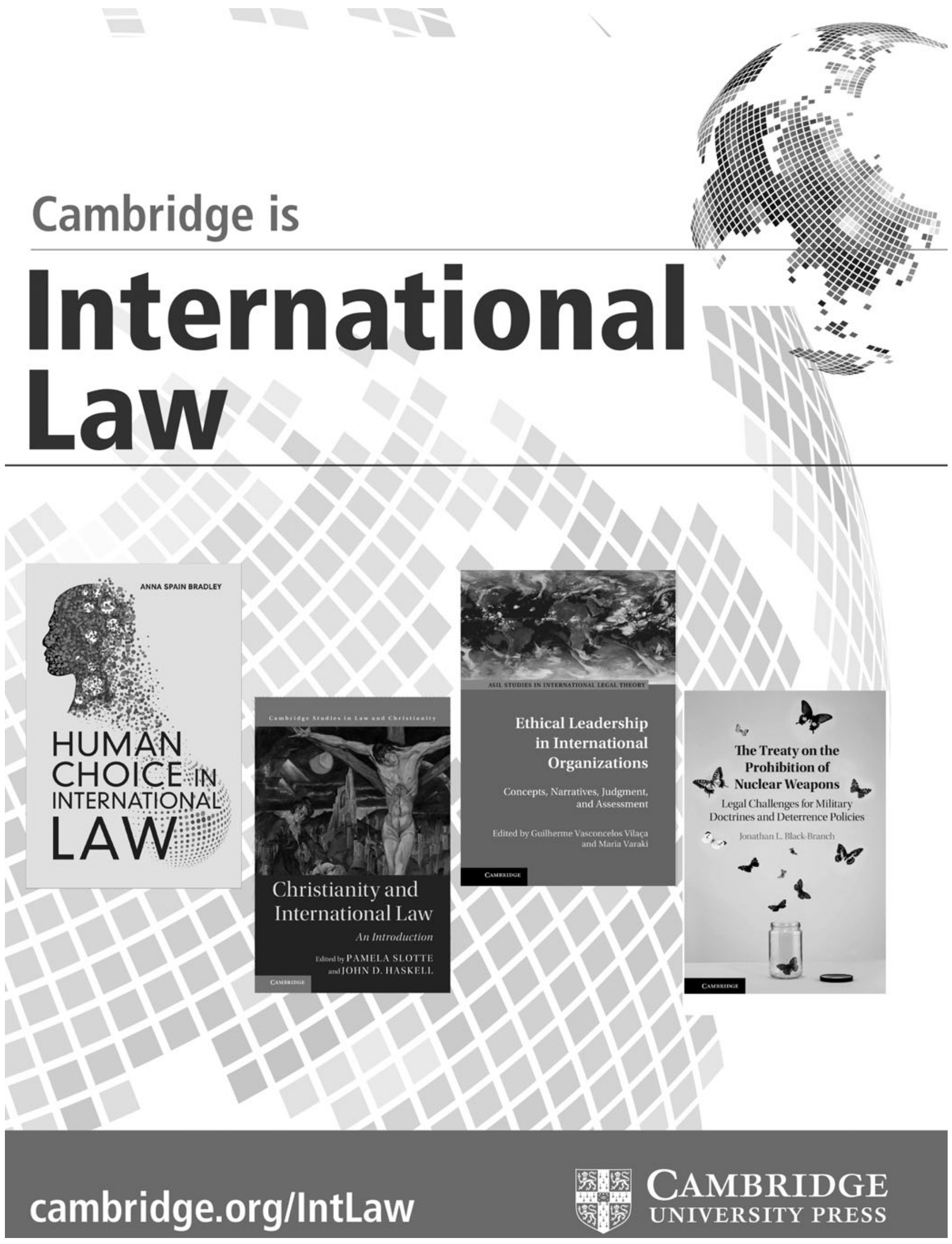




\section{Cambridge University Press}

Home to a diverse range of journals in INTERNATIONAL LAW
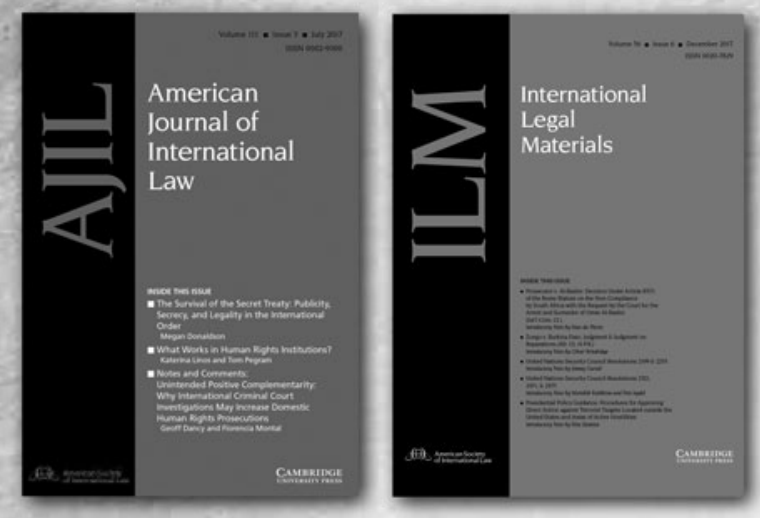

Leiden journal

of international Law

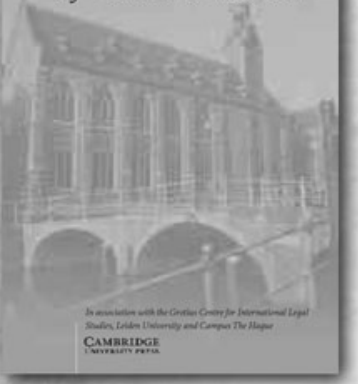

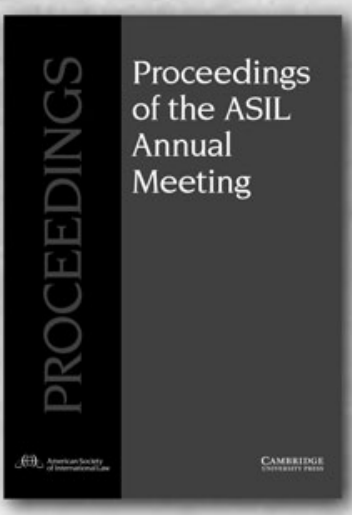

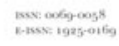

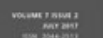

Asian Journal of International Law

THE CANADLAN YEARBOOK OF

INTERNATIONAL LAW

vousas $54 \quad 2016$ TOME 54
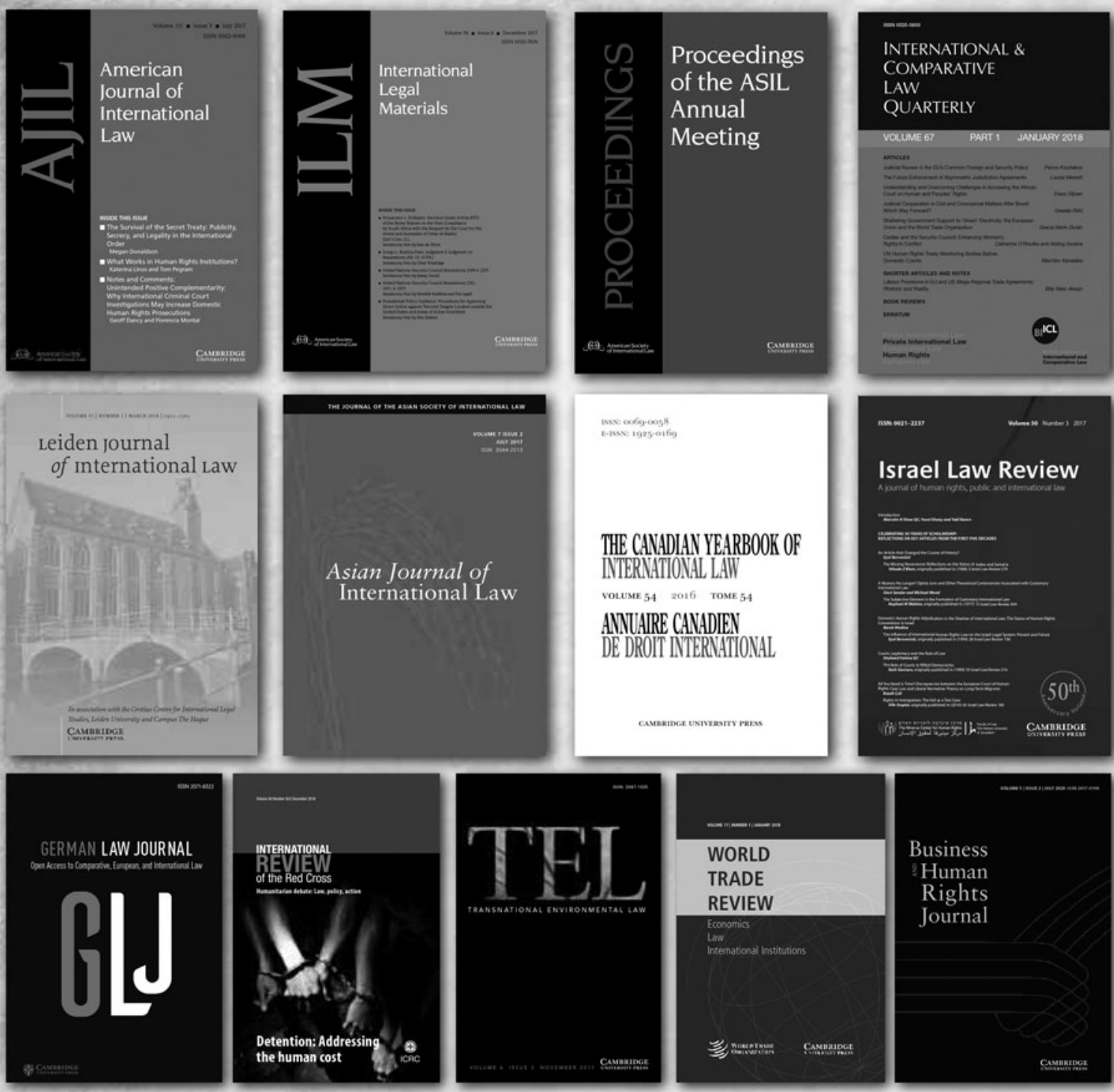

Israel Law Review

ANUAIRE CANADEN

DE DROIT INTERNATIONAL
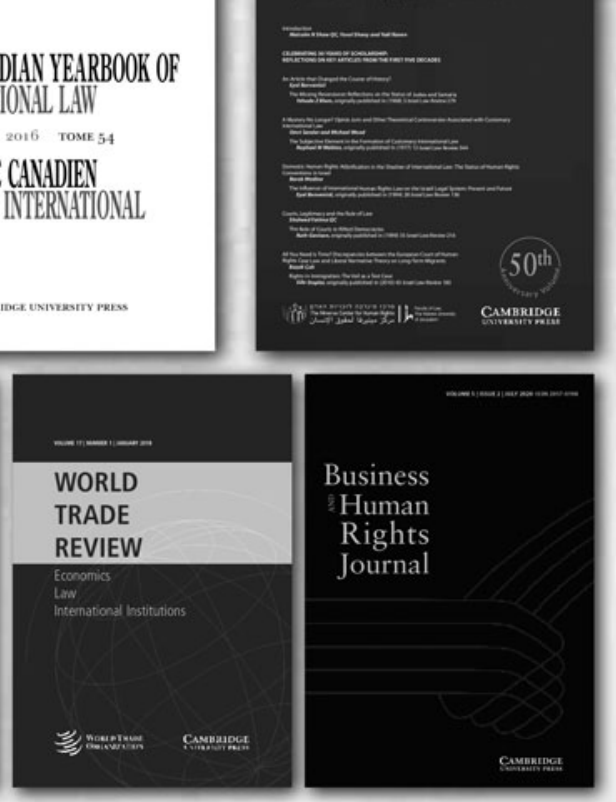

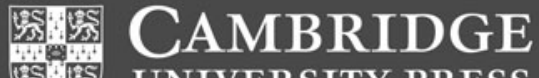
UNIVERSITY PRESS 


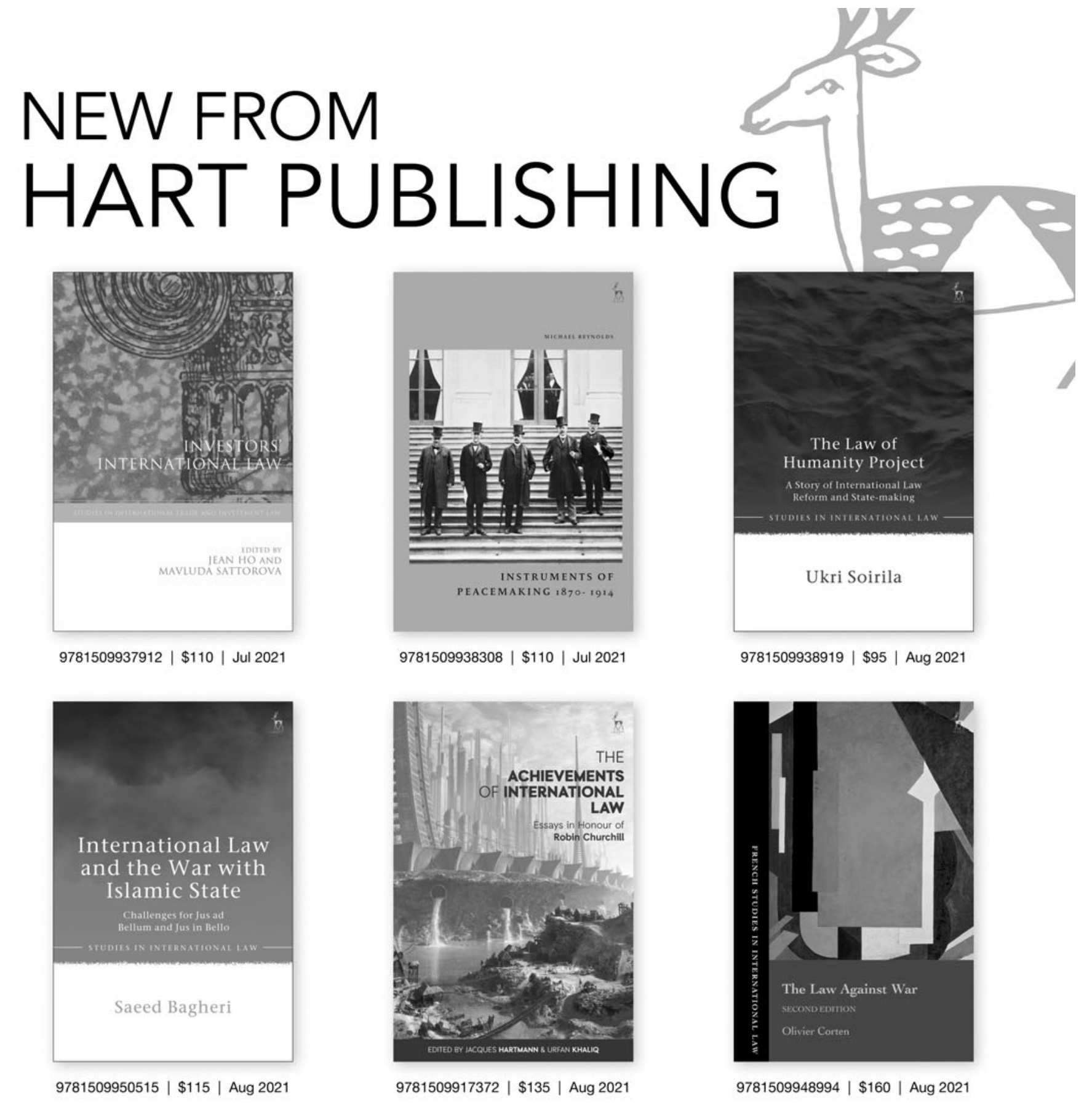

- Let AR LaA 2

EXCELLENCE AND ORIGINALITY IN LEGAL SCHOLARSHIP

Hart Law on Bloomsbury Collections
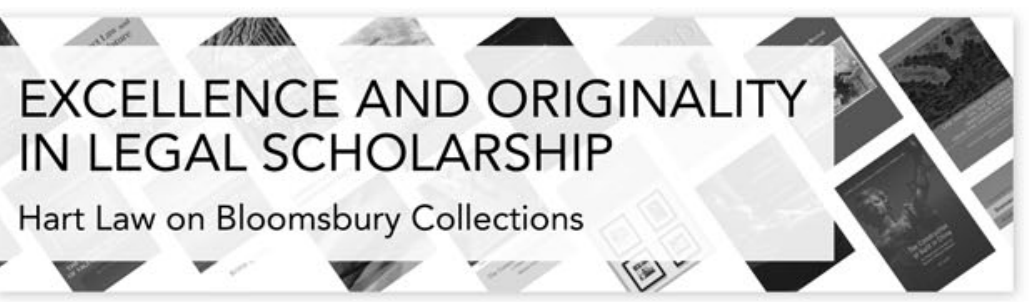

Use Promo Code HARTUS20 for a $20 \%$ discount 


\section{OXFORD}

UNIVERSITY PRESS

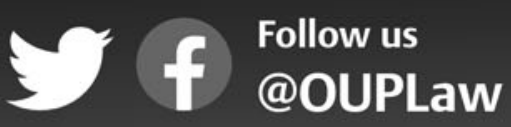

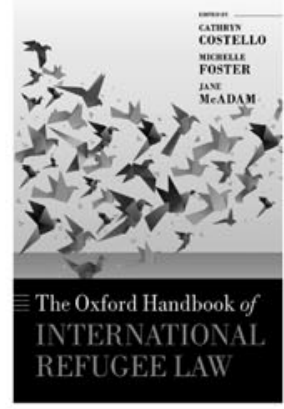
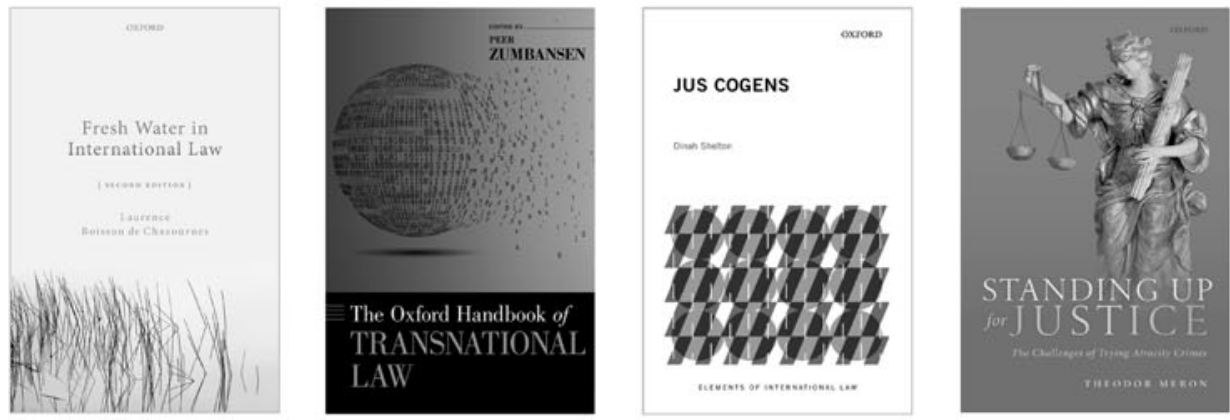

The Oxford Handbook of International Refugee Law

Edited by Cathryn Costello, Michelle Foster, and Jane McAdam

2021 | 1264 pp.

9780198848639 | Hardcover | \$190.00

Fresh Water in International Law Second Edition

Laurence Boisson de Chazournes

2021 | 368 pp.

9780198863427 | Hardcover | \$125.00

Contingency in International Law: On the Possibility of Different Legal Histories

Edited by Ingo Venzke and Kevin Jon Heller 2021 | 576 pp.

9780192898036 | Hardcover | \$125.00

The Handbook of International

Humanitarian Law

Fourth Edition

Edited by Dieter Fleck

$2021 \mid 816$ pp.

$9780198847960 \mid$ | Hardcover | \$210.00

Postgenocide: Interdisciplinary

Reflections on the Effects of Genocide

Edited by Klejda Mulaj

2021 | 336 pp.

9780192895189 | Hardcover | \$99.00
Jus Cogens

Dinah Shelton

Elements of International Law

2021 | 144 pp.

9780198865964 | Paperback | \$25.95

9780198865957 | Hardcover | \$90.00

The Oxford Handbook of Transnational

Law

Edited by Peer Zumbansen

2021 | 1248 pp.

9780197547410 | Hardcover | $\$ 190.00$

The Occupation of Justice: The Supreme Court of Israel and the Occupied

Territories

Second Edition

David Kretzmer and Yaël Ronen

2021 | 560 pp.

9780190696023 | Hardcover | \$125.00

Migration and the European

Convention on Human Rights

Edited by Başak Çalı, Ledi Bianku,

and Iulia Motoc

European Society of International Law

2021 | 288 pp.

9780192895196 | Hardcover | $\$ 99.00$

The European Union and Human

Rights: Analysis, Cases, and Materials

Jan Wouters and Michal Ovádek

$2021 \mid 752$ pp.

9780198814184 | Paperback | \$60.00

9780198814177 | Hardcover | \$165.00
Standing Up for Justice: The Challenges of Trying Atrocity Crimes

Theodor Meron

2021 | 400 pp.

9780198863434 | Hardcover | \$32.95

The Oxford Handbook of the International Law of Global Security Edited by Robin Geiß and Nils Melzer 2021 | 1200 pp.

9780198827276 | Hardcover | \$190.00

Multinational Enterprises and the Law Third Edition Peter Muchlinski

Oxford International Law Library $2021 \mid 864 \mathrm{pp}$.

9780198824145 | Paperback | \$65.00 9780198824138 | Hardcover | \$195.00

Reframing Human Rights in a

Turbulent Era

Gráinne de Búrca

2021 | 304 pp.

9780199246007 | Paperback | \$46.95

9780198299578 | Hardcover | $\$ 99.00$

The International Tribunal for the Law of the Sea

Kriangsak Kittichaisare

2021 | 240 pp.

9780198865346 | Paperback | \$25.95

9780198865292 | Hardcover | \$90.00
Elements of International Law

\section{Visit global.oup.com/academic to place your order and enter ASIL at checkout to save $25 \%$}


https://doi.org/10.1017/ilm.2021.24 Published online by Cambridge University Press 